\title{
CG31320 (Heatr2) - ciliopathy candidate gene, functional analysis in fly and mouse models
}

\author{
G Mali ${ }^{1 *}$, P Mill ${ }^{1}$, Pl zur Lage ${ }^{2}$, EA Hall ${ }^{1}$, AP Jarman², IJ Jackson ${ }^{1}$ \\ From First International Cilia in Development and Disease Scientific Conference (2012) \\ London, UK. 16-18 May 2012
}

The structural and functional roles of many of the 800-1000 proteins that make up the microtubule core and specialized membranes of cilia and flagella are poorly understood. Following from our recent expression study to identify putative ciliary candidates in Drosophila sensory neurons, we focused on a subset that were targets of the transcription factor Fd3f, which regulates functional specialization of mechanosensory cilia. Bioinformatic enrichment for known ciliary domains as well as orthologous proteinprotein interaction network modelling provided a list of putative ciliary genes for further functional characterization. One such candidate, CG31320, has been initially characterized in Drosophila. Little is known about this gene, except the encoded protein contains HEAT repeats - belonging to an armadillo-like fold family associated with intracellular transport. In situ analysis confirms that CG31320 mRNA is highly expressed in the ciliated chordotonal neurons. RNAi-mediated knock-down resulted in abnormal chordotonal ciliary morphology and locomotory defects, consistent with impaired mechanosensory cilium function. Currently, we are studying whether the ortholog Heatr2 is also required for mammalian cilia. Protein localization studies suggest that Heatr2 plays a role in trafficking to primary cilia. RNAi knock-down and protein interaction studies using mammalian cells are underway to functionally dissect Heatr2 roles; results will be presented. We are generating a Heatr2 conditional mouse mutant to investigate its function in different types of cilia and sperm flagella. We present a multisystem experimental pipeline for functional characterization of novel genes expressed in cilia as well as putative ciliopathy candidates.

\section{Author details}

${ }^{1}$ MRC Human Genetics Unit, MRC IGMM, University of Edinburgh, UK.

${ }^{2}$ University of Edinburgh, UK.

Published: 16 November 2012

doi:10.1186/2046-2530-1-S1-P92

Cite this article as: Mali et al:: CG31320 (Heatr2) - ciliopathy candidate gene, functional analysis in fly and mouse models. Cilia 2012 1(Suppl 1): P92.

* Correspondence: Girish.Mali@hgu.mrc.ac.uk

${ }^{1}$ MRC Human Genetics Unit, MRC IGMM, University of Edinburgh, UK

Full list of author information is available at the end of the article

Submit your next manuscript to BioMed Central and take full advantage of:

- Convenient online submission

- Thorough peer review

- No space constraints or color figure charges

- Immediate publication on acceptance

- Inclusion in PubMed, CAS, Scopus and Google Scholar

- Research which is freely available for redistribution
C Biomed Central

(0) 2012 Mali et al; licensee BioMed Central Ltd. This is an Open Access article distributed under the terms of the Creative Commons Attribution License (http://creativecommons.org/licenses/by/2.0), which permits unrestricted use, distribution, and reproduction in any medium, provided the original work is properly cited. 